\title{
Media Pembelajaran Multimedia Interaktif Agama Islam Untuk Anak menggunakan Macromedia Flash 8
}

\author{
Muhammad Ibrahim Nasution ${ }^{1}$, Febria Rahim ${ }^{2}$, Nofianti $^{3}$ \\ ${ }^{1,3}$ Prodi Manajemen Informatika, Jurusan Teknologi Informasi, Akademi Komunitas Negeri Tanah \\ Datar \\ Jln. Raya Tigo Jangko Lintau Buo, Kabupaten Tanah Datar, Sumatera Barat, 27292 \\ Email: udabaimnst90@gmail.com,nofianti1197@gmail.com \\ 2 Jurusan Ekonomi Syariah, Fakultas Ekonomi dan Bisnis Islam, Institut Agama Islam Negeri \\ Batusangkar \\ Jl. Sudirman No.137 Kuburajo Lima Kaum Batusangkar, Sumatera Barat 27213 \\ Email: feb_rhia@yahoo.co.id
}

\begin{abstract}
ABSTRAK
Perkembangan teknologi multimedia menjadikan pembelajaran lebih efektif dalam menyampaikan pengetahuan, keterampilan, sikap dan motivasi anak, sehingga proses pembelajaran menjadi lebih bermakna, bertujuan serta menyenangkan. pembuatan aplikasi multimedia interaktif bertujuan sebagai alternatif pembelajaran yang efektif, meningkatkan daya minat anak-anak dalam mempelajari agama islam serta dapat mempermudah orang tua untuk mengenalkan agama islam kepada anak-anak. Proses pembuatan media pembelajaran mulai dari observasi, studi literatur, referensi, perancangan, implementasi hingga pengujian. Media pembelajaran ini menggunakan media digital yang beroperasi pada komputer atau laptop, sehingga dapat membantu memperluas pemahaman tentang agama islam. Media Pembelajaran ini dibangun menggunakan aplikasi Macromedia Flash 8. Untuk pengujian menggunakan metode Black Box Test yaitu menguji fungsi dalam setiap menu dan tombol telah berjalan dengan semestinya. Dengan Menggunakan Media pembelajaran ini diharapkan dapat membantu kegiatan belajar mengajar, sehingga anak-anak tidak merasa jenuh dan bosan
\end{abstract}

Kata Kunci: Multimedia Interaktif, Pembelajaran, Agama Islam

\section{ABSTRACT}

The development of multimedia technology makes learning more effective in conveying children's knowledge, skills, attitudes and motivations, so the learning process becomes more meaningful, purposeful and enjoyable. making interactive multimedia applications aim as an alternative to effective learning, increase children's interest in learning the religion of Islam and can make it easier for parents to introduce Islam to children. The process of making learning media ranging from observation, study of literature, reference, design, implementation to testing. This learning media uses digital media that operates on a computer or laptop, so that it can help broaden understanding of the Islamic religion. This Learning Media was built using the Macromedia Flash 8 application. For testing using the Black Box Test method, namely testing the functions in each menu and button are running properly. Using this learning media is expected to help teaching and learning activities, so that children do not feel bored and bored

Keywords: interactive multimedia, learning, islamic religion

\section{Pendahuluan}

Dalam dunia pendidikan sekarang ini banyak orang tua yang memberikan keterangan mengenai agama dengan cara menceritakan. Dengan cara itu anak-anak akan susah menangkap makna yang sedang disampaikan orang tua karena dianggap kurang menarik. Pengetahuan masyarakat tentang pendidikan agama semakin lama semakin menipis, yang dahulunya anak-anak mengaji kesurau atau musholla, dan sekarang keinginan untuk mengetahui agama semakin berkurang.

Dengan dilakukan penerapan pembelajaran agama terutama pengenalan nama-nama nabi, tata cara wudhu, dan tata cara sholat, pada masyarakat Indonesia sejak dini, diharapkan akan lebih mudah diterima apabila diterapkan pada usia yang masih muda. Dengan tampilan multimedia yang didesain dan dimodifikasi menarik anak-anak akan lebih cepat mengerti dan memahami yang sedang dipelajarinya. Pembuatan media pembelajaran yang interaktif dan kreatif kini telah banyak tersedia. 
Disamping banyak modelnya, menggunakan dan mendapatkannya sangat mudah. Macromedia Flash 8 adalah salah satu contoh program membuat media pembelajaran.

Kelebihan dari Macromedia Flash 8 adalah mampu menggabungkan gambar, teks, animasi dan suara. Selain itu program tersebut memberikan tombol interaktif, Mengubah bentuk animasi, mampu menggerakkan animasi mengikuti alur dan bisa di Publish. Sehingga dapat menjadikan pembelajaran lebih menyenangkan, mengasyikkan dan menjadikan peserta didik tertarik dengan materi yang diajarkan.

Kurangnya pengetahuan anak-anak sekarang mengenai agama islam maka berinisiatif untuk membuat game sebagai media pengenalan agama islam tentang nama-nama nabi, wudhu, dan sholat. Oleh sebab itu dibuatlah Media Pembelajaran Multimedia Interaktif tentang Agama Islam Untuk Anak menggunakan Macromedia Flash 8 .

"Multimedia terdiri dari dua kata "multi" artinya banyak, dan "media" sesuatu yang dipakai untuk meyampaikan atau membawakan sesuatu" [1]. Dalam bidang komputer, multimedia merupakan aplikasi dan presentasi berbasis komputer yang menggabungkan beberapa media, seperti teks, suara, gambar, video, dan animasi. Dengan menggunakan multimedia pada komputer mampu membuat komputer menjadi lebih mudah dipakai, lebih nyaman, lebih menyenangkan dan lebih menarik bagi pemakai.

"Multimedia interaktif pembelajaran dapat digunakan menyalurkan informasi berupa materi pelajaran, meningkatkan perhatian dan minat peserta didik sehingga menghasilkan proses belajar yang lebih baik" [2]. Penyajian materi pelajaran menggunakan multimedia interaktif bisa memudahkan siswa dalam memahami materi yang sulit menjadi mudah.

"Macromedia flash 8 adalah aplikasi yang dapat menampilkan teks, gambar, animasi, dan audio secara bersama, maka sangat mungkin apabila macromedia flash 8 digunakan sebagai sarana pengembangan media pembelajaran" [3].

"Media pembelajaran dapat memperjelas penyajian pesan dan informasi sehingga dapat memperlancar serta meningkatkan proses dan hasil belajar siswa, media pembelajaran dapat meningkatkan dan mengarahkan perhatian siswa sehingga dapat menimbulkan motivasi belajar"[4]. Media pembelajaran merupakan media yang mampu membantu proses belajar mengajar sehingga pesan yang akan disampaikan diterima dengan jelas, tujuan pembelajaran dapat tercapai dengan lebih baik dan sempurna tersampaikan ke siswa.

"Pendidikan Islam sebagai proses yang mengarahkan manusia kepada kehidupan yang baik dan mengangkat derajat kemanusiaan sesuai dengan kemampuan dasar (fitrah), penting sekali di berikan kepada peserta didik, terutama dalam mengantisipasi krisis moral sebagai dampak negatif dari era globalisasi yang melanda bangsa Indonesia" [5].

Flowchart adalah penggambaran secara grafik dari langkah-langkah dan urut-urutan prosedur dari suatu program. Flowchart menolong analis dan programmer untuk memecahkan masalah kedalam segmen-segmen yang lebih kecil dan menolong dalam menganalisis alternatif-alternatif lain dalam pengoperasian [6].

\section{Metode Penelitian}

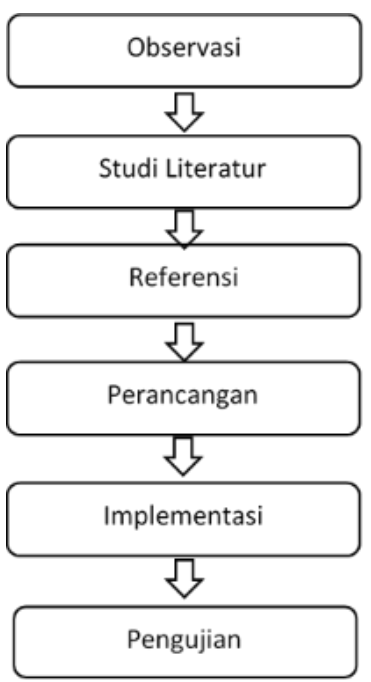

\section{Gambar 1 Metodelogi Penelitian}

Berdasarkan gambar 1 menjelaskan metodelogi yang digunakan, adapun penjelasannya akan dijelaskan sebagai berikut :

1. Observasi

Melakukan diskusi dan pembahasan dengan pihak yang terkait dalam pembuatan media pemebelajaran ini.

2. Studi Literatur

Merupakan metode proses pengumpulan data dengan cara melakukan studi kepustakaan melalui membaca dari buku atau jurnal ilmiah yang berkaitan dalam Pembuatan media pembelajaran Multimedia Interaktif Pembelajaran Agama Islam Untuk Anak menggunakan macromedia flash 8

3. Referensi

Pengumpulan data dan berbagai macam informasi terkait melalui referensi dari buku, modul, jurnal maupun internet yang berkaitan dengan topik tersebut.

4. Perancangan 
Pada tahap perancangan, dirancang letak teks, gambar dan suara serta script-script yang di butuhkan dalam menyampaikan informasi.

5. Implementasi

Setelah proses perancangan selesai, proses selanjutnya adalah mengimplementasi sistem berdasarkan hasil perancangan Multimedia Interaktif Sebagai Media Pembelajaran Agama Islam Untuk Anak dilakukan dengan menggunakan Aplikasi Macromedia Flash 8

6. Pengujian

Setelah proses implementasi berhasil, selanjutnya dilakukan pengujian terhadap sistem sehingga didapatkan informasi apakah sistem sudah sesuai dengan harapan yang diinginkan.

\section{Analisa Kebutuhan Perangkat keras}

Analisa kebutuhan perangkat keras bertujuan untuk mengetahui secara tepat perangkat keras yang dibutuhkan. Adapun hardware yang dibutuhkan pad pembuatan Media Pembelajaran ini Seperangkat Komputer dengan spesifikasi, Processor : Intel Celeron 1.60 GHz, RAM 2GB, Hardisk 320 GB, Monitor, Keyboard dan Mouse

\section{Analisa Kebutuhan Perangkat Lunak}

Analisis kebutuhan perangkat keras bertujuan untuk mengetahui perangkat lunak yang dibutuhkan. Adapun Perangkat lunak yang dibutuhkan dalam pembuatan media pembelajaran ini adalah Windows 10, Macromedia Flash 8, dan Audacity

\section{Struktur Program}

Pada rancangan struktur program terdapat menu utama yang terdiri dari empat submenu yaitu materi, game, petunjuk, about. Pada menu materi terdapat submenu kisah 25 nabi dan rasul, tata cara wudhu dan tata cara shalat. Pada menu game terdapat dua submenu yaitu objektif dan tampung air seperti pada gambar 2

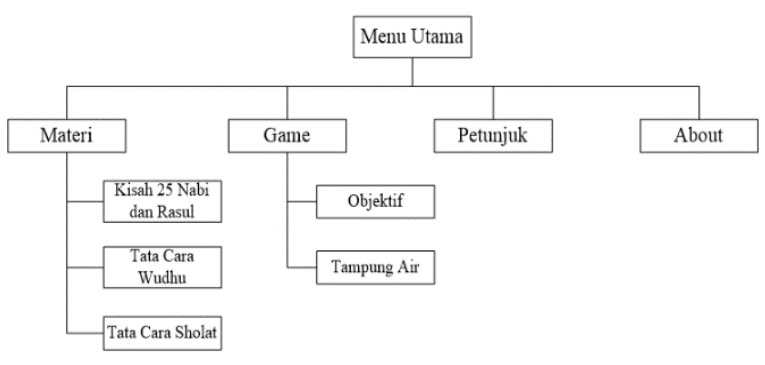

Gambar 2 Struktur Program

\section{Flowchart Menu Utama}

Rancangan flowchart ini dimulai dari start, kemudian masuk ke halaman utama. Pada halaman utama terdapat pada menu yaitu : menu materi, menu game, menu petunjuk, dan menu about. Pada halaman materi terdapat tiga keputusan yaitu kisah 25 nabi dan rasul, tata cara wudhu, tata cara sholat, pada halaman menu game terdapat dua keputusan yaitu game objektif, dan game tampung air, pada halaman petunjuk akan menampilkan halaman petunjuk, dan pada halaman about akan menampilkan halaman about. Gambar 3 merupakan hasil rancangan flowchart.

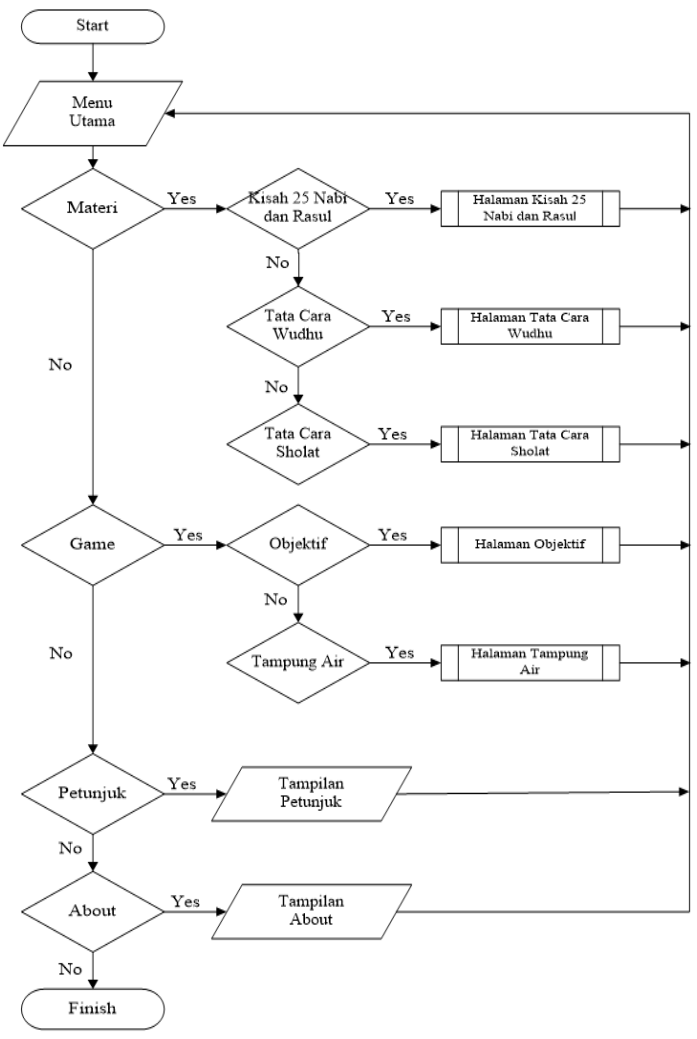

Gambar 3 Flowchart Menu Utama

\section{Flowchart Halaman Kisah 25 Nabi dan Rasul}

Pada rancangan flowchart tata cara sholat terdapat 25 menu yaitu adam, idris, nuh, hud, shaleh, luth, ibrahim, ismail, ishaq, yakub, yusuf, ayub, suib, musa, harun, zulkifli, daud, sulaiman, ilyas, ilyasa, yunus, zakaria, yahya, isa, muhammad. Setiap menu memiliki keputusan, jika keputusan benar maka akan menuju ke halaman nabi dan jika keputusan salah makan akan kembali ke halaman 25 nabi dan rasul. Seperti pada gambar 4 


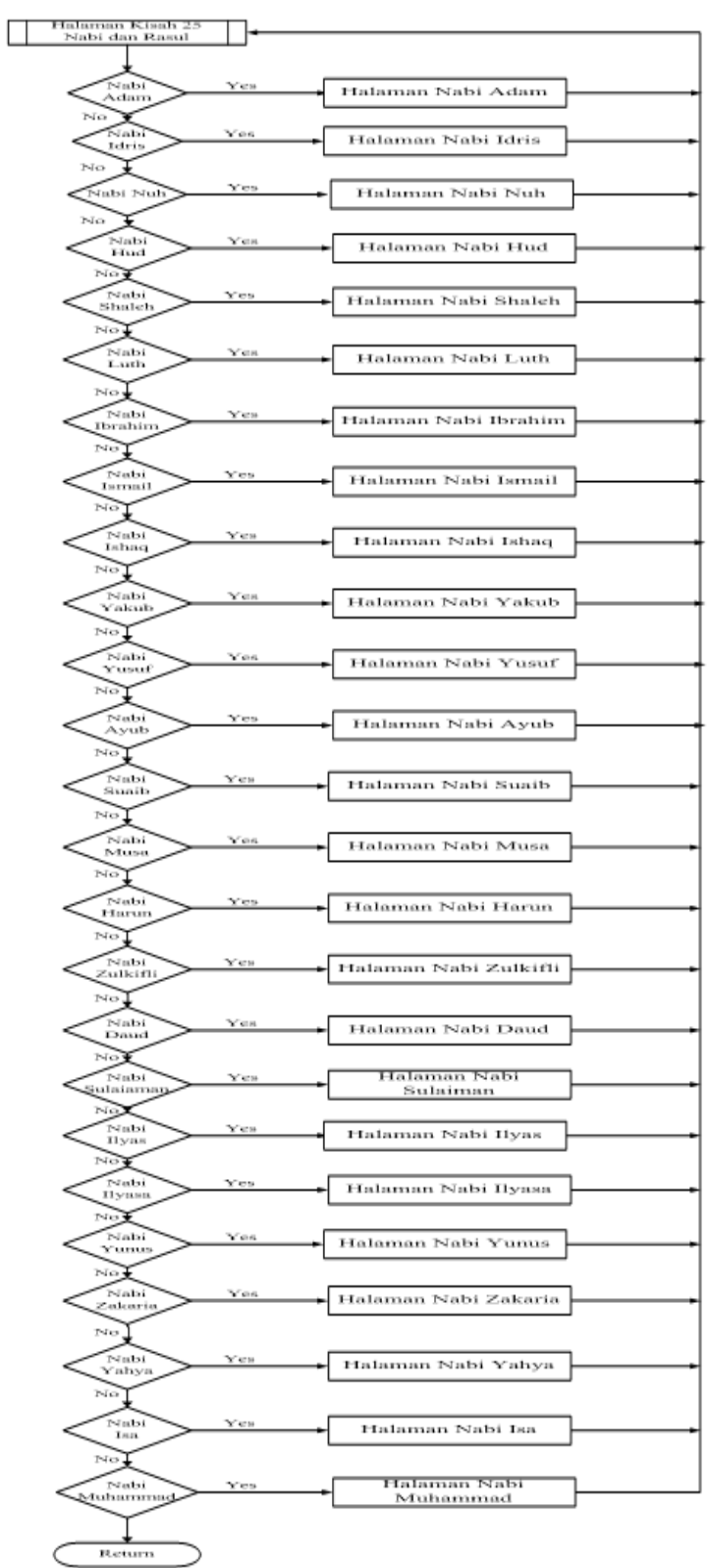

Gambar 4. Flowchart Halaman Kisah 25 Nabi dan Rasul

\section{Flowchart Halaman Tata Cara Wudhu}

Pada rancangan flowchart tata cara sholat terdapat sembilan menu yaitu persiapan wudhu, niat wudhu, berkumur, membasuh muka, membasuh tangan, membasuh kening dan rambur, membasuh telinga, membasuh kaki dan berdoa . Pada setiap menu memiliki keputusan yang jika benar maka akan menuju ke halaman wudhu dan jika tidak akan kembali ke halaman tata cara wudhu. Seperti pada gambar 5

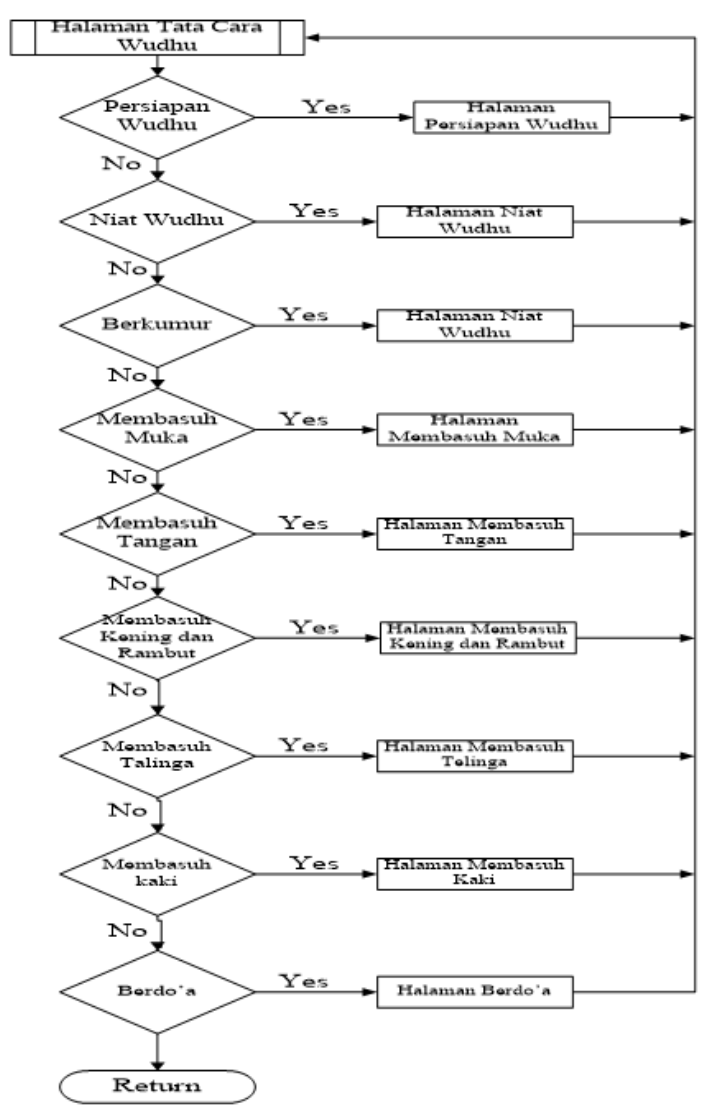

Gambar 5. Flowchart Halaman Tata Cara Wudhu

\section{Flowchart Halaman Tata Cara Sholat}

Pada rancangan flowchart tata cara sholat terdapat lima menu yaitu subuh, dzuhur, ashar, magrib, isya. Pada menu subuh akan masuk ke halaman sholat subuh. Pada menu dzuhur akan masuk ke halaman sholat dzuhur. Pada menu ashar akan masuk ke halaman sholat ashar. Pada menu magrib akan masuk ke halaman sholat magrib Pada menu isya akan masuk ke halaman sholat isya. Seperti pada gambar 6

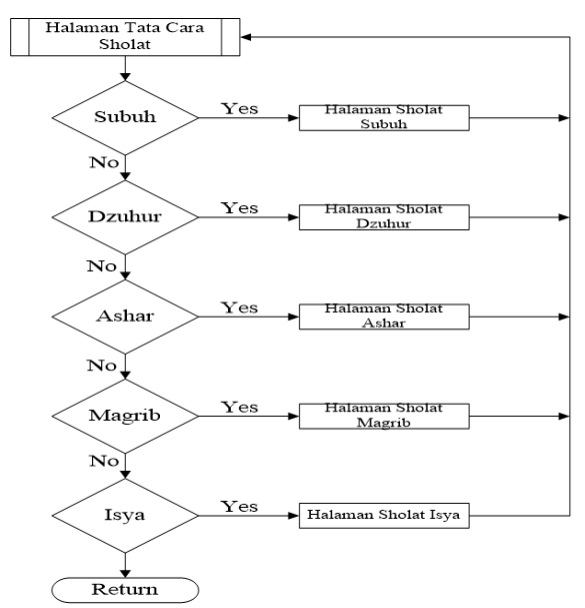

Gambar 6 Flowchart Halaman Tata Cara Sholat 


\section{Rancangan Antar Muka}

Sebelum membuat Media Pembelajaran Multimedia Interaktif tentang Agama Islam Untuk Anak, diharapkan membuat rancangan desain tampilannya. Rancangan desain tampilan pada aplikasi multimedia ini terdiri dari halaman intro, 4 menu utama yaitu menu materi, game, petunjuk, tentang dan 7 submenu yaitu submenu, materi nabi, materi wudhu, materi sholat, game objektif, game tampung air, petunjuk dan about.

\section{Rancangan Halaman Intro}

Halaman intro merupakan halaman paling awal yang tampil ketika program media pembelajaran dijalankan. Pada halaman ini menampilkan Text sebagi judul media pembelajaran, button 1 digunakan untuk materi, button 2 digunakan untuk petunjuk, button 3 digunakan untuk game, button 4 digunakan untuk tentang. dan tombol game untuk memulai penggunaan media pembelajaran agama islam. Tampilan rancangan halaman intro dapat dilihat pada Gambar 7

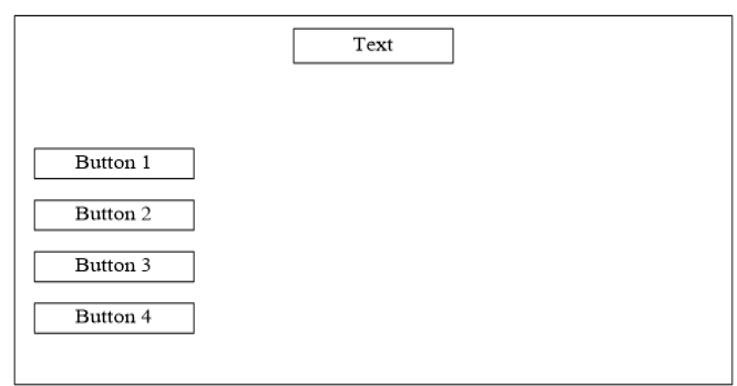

Gambar 7. Rancangan Halaman Intro

\section{Rancangan Halaman Utama Materi}

Halaman materi ini digunakan untuk mempelajari nama-nama nabi, sholat dan wudhu. Dihalaman ini terdapat satu text untuk judul, 7 button button 1 untuk materi, button 2 untuk petunjuk dan button 3 untuk game, dan button 4 untuk tentang, button 5 untuk materi nabi, button 6 untuk tata cara wudhu, button 7 untuk tata cara sholat. Tampilan rancangan halaman menu utama materi dapat dilihat pada Gambar 8

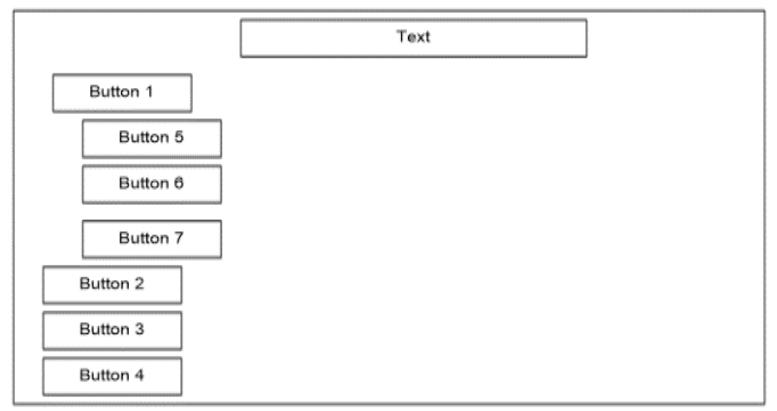

Gambar 8 Rancangan Halaman Utama Materi

\section{Halaman Materi Nabi}

Dihalaman materi nabi digunakan untuk mempelajari 25 nabi dan rasul. Dihalaman ini terdapat satu text, dan 26 button. Text digunakan untuk cerita nabi, button 1 sampai 25 nama nabi, dan button 26 unutk kembali Tampilan rancangan halaman materi dapat dilihat pada Gambar 9

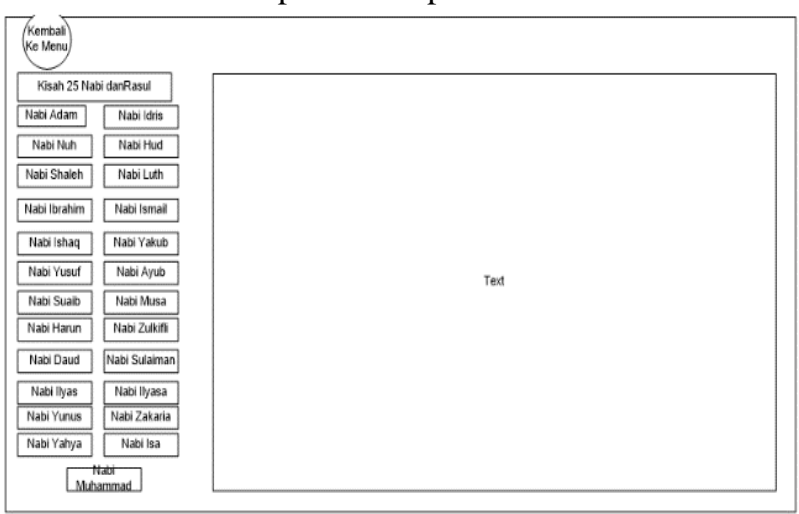

Gambar 9 Halaman Materi Nabi

\section{Rancangan Halaman Utama Wudhu'}

Rancangan halaman utama wudhu terdapat text sebagai tata cara sholat, dan 10 button. Untuk buton 1 persiapan wudhu', button 2 niat wudhu', button 3 berkumur, button 4 membasuh muka, button 5 membasuh tangan, dan button 6 mengusap kening dan rambut, button 7 membasuh telinga, button 8 membasuh kaki, button 9 berdo'a. Tampilan rancangan halaman utama wudhu' dapat dilihat pada Gambar 10

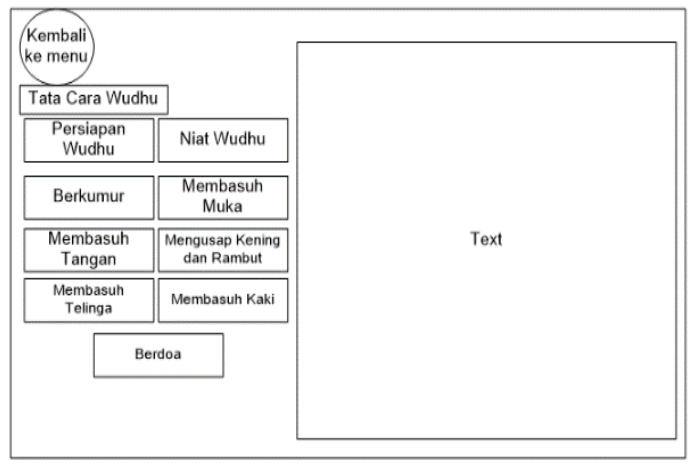

Gambar 10. Rancangan Halaman Utama

\section{Rancangan Halaman Utama Shalat}

Rancangan halaman utama Shalat terdapat text sebagai tatacara sholat, dan 7 button. Untuk buton 1 terdapat tatacara sholat, button 2 sholat subuh, button 3 sholat dzuhur, button 4 sholat ashar, button 5 sholat magrib, button 6 sholat isya, dan button 7 untuk tombol kembali kemenu utama. Tampilan rancangan halaman utama shalat dapat dilihat pada Gambar 11 


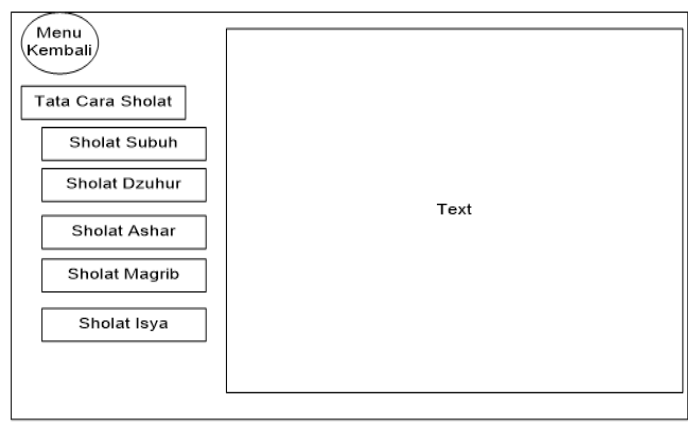

Gambar 11 Rancangan Halaman Utama Shalat

\section{Hasil dan Pembahasan}

Implementasi aplikasi merupakan implementasi dari desain yang telah dirancang sebelumnya.

\section{Tampilan Halaman Intro}

Tampilan intro merupakan halaman awal yang muncul ketika aplikasi Game dijalankan. Pada halaman ini terdapat 4 tombol, yaitu tombol materi, game, petunjuk, dan about. dan tombol tersebut juga digunakan ActionScript untuk masuk ke halaman menu lainya.

on (release) \{gotoAndStop (10);\}

Berikut tampilan halaman intro seperti pada gambar 12

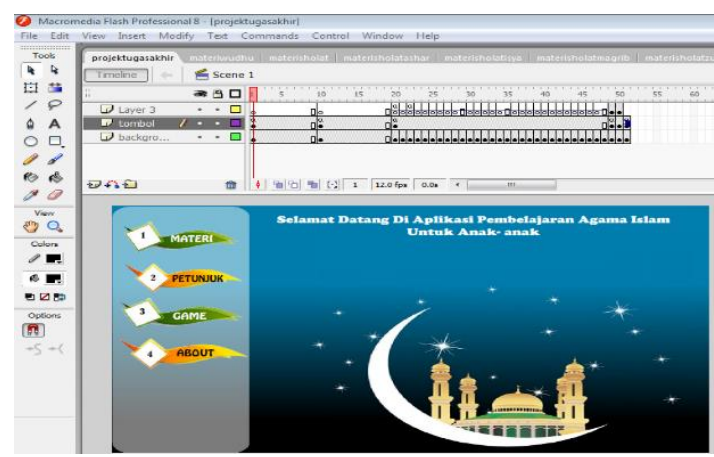

Gambar 12 Tampilan Rancangan Halaman Intro

\section{Tampilan Halaman Utama Materi}

Pada menu utama materi akan menampilkan pilihan materi. Pada halaman terdapat 4 tombol (menu), antara lain menu 25 nabi dan rasul, menu tata cara wudhu, menu tata cara sholat, home. dan tombol tersebut juga digunakan ActionScript untuk memanggil menu tersebut, 25 nabi dan rasul. on (release) \{gotoAndStop $(20) ;\}$

Berikut tampilan halaman utama materi seperti gambar 13

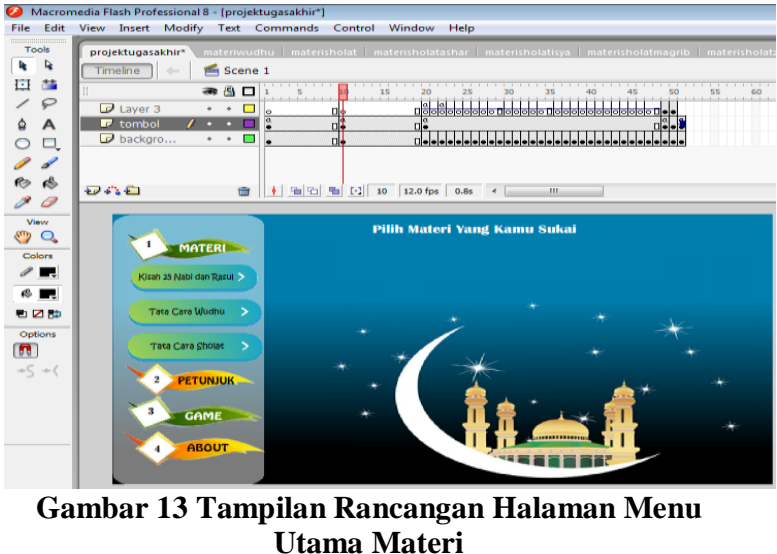

\section{Tampilan Halaman Materi Nabi}

Pada halaman materi akan menampilkan pilihan materi 25 nabi dan rasul. Pada halaman terdapat 26 tombol (menu), antara lain menu nabi adam sampai nabi muhammad, dan menu exit dan tomol ini juga digunakan ActionScript untuk memanggil menu tersebut. on (release)\{stopAllSounds();gotoAndStop(20);\}

Berikut tampilan halaman materi nabi seperti gambar 14

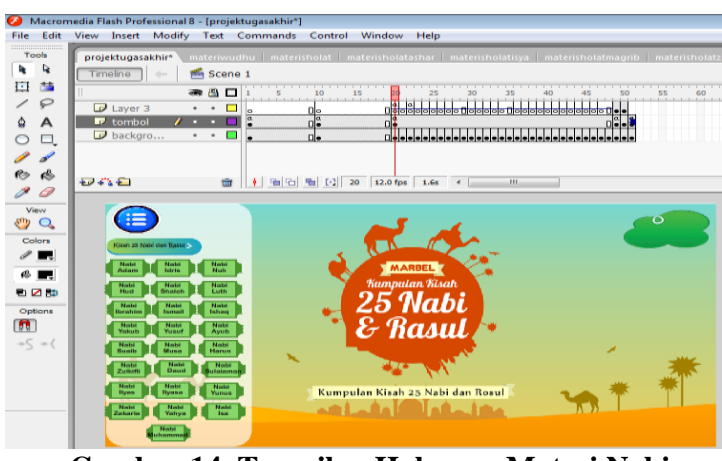

Gambar 14. Tampilan Halaman Materi Nabi

\section{Tampilan Halaman Nabi}

Tampilan ini berfungsi untuk menampilkan cerita nabi dengan diiringi musik terdapat tombol menu untuk kembali ke halaman materi nabi dari user yang ActionScriptnya :

on (release) \{gotoAndStop(21); stopAllSounds();\}

Berikut tampilan halaman nabi seperti gambar

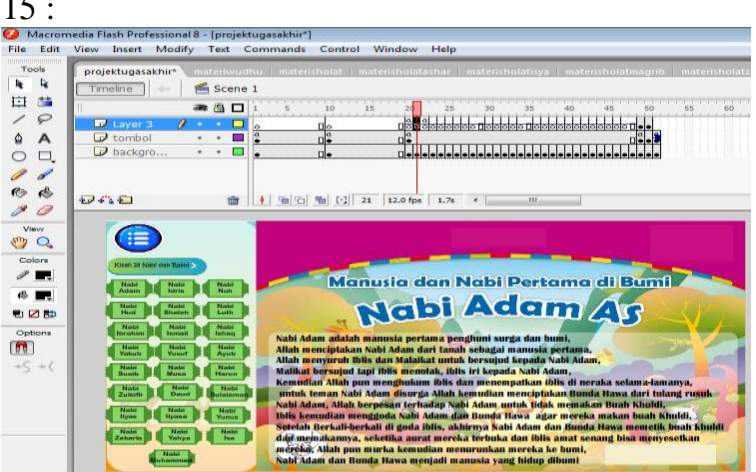

Gambar 15. Tampilan Halaman Nabi 


\section{Tampilan Halaman Utama Wudhu'}

Tampilan ini berfungsi untuk menampilkan tata cara berwudhu', niat wudhu, berkumur, membasuh tangan, mengusap kening dan rambut, membasuh telinga, membasuh kaki, berdo'a, yang pertama dari user yang ActionScriptnya :

on(release)\{loadMovieNum("materiwudhu.swf",0);

Berikut tampilan halaman utama wudhu' seperti gambar 16

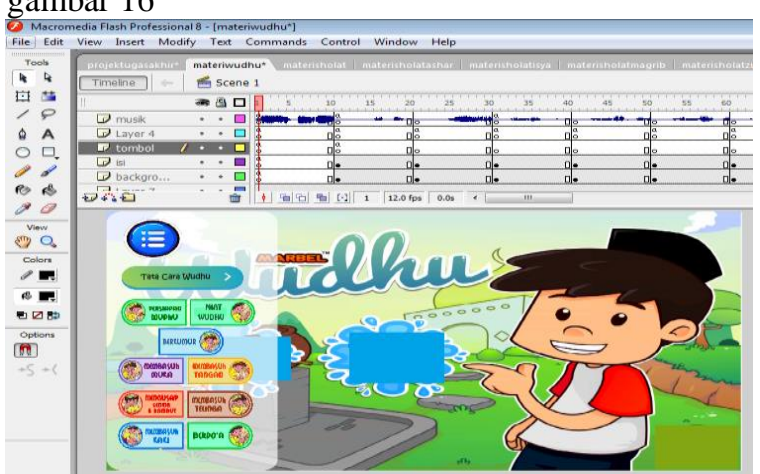

Gambar 16 Tampilan Halaman Utama Wudhu'

\section{Tampilan Halaman Wudhu}

Tampilan ini berfungsi untuk menampilkan tata cara wudhu' dengan diiringi musik terdapat tombol menu untuk kembali ke halaman materi wudhu' dari user yang ActionScriptnya :

on (release) \{gotoAndStop (11); \}

Berikut tampilan halaman wudhu' seperti gambar 17

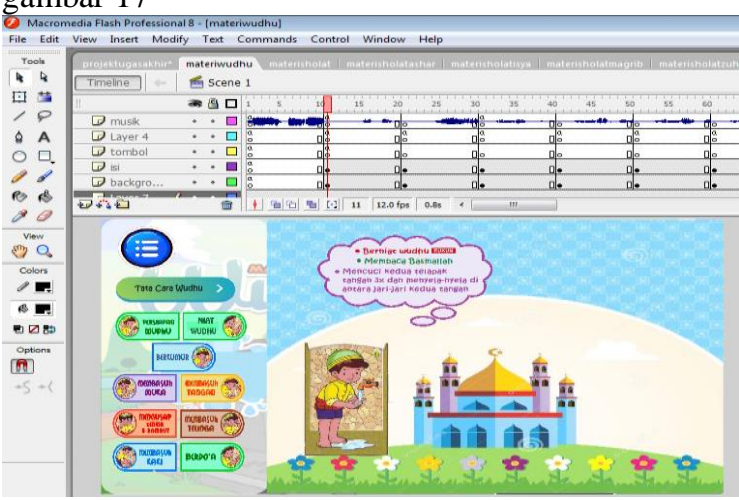

Gambar 17 Tampilan Halaman Wudhu'

\section{Tampilan Halaman Utama Sholat}

Pada menu utama sholat ini akan menampilkan pilihan sholat subuh, sholat zuhur, sholat ashar, sholat magrib, sholat isya, dan menu-menu ini juga digunakan ActionScript untuk memanggil menu tersebut, seperti sholat subuh.

$$
\text { on }
$$

(release)

\{loadMovieNum("materisholat.swf",0);\}

Berikut tampilan halaman utama sholat seperti gambar 18

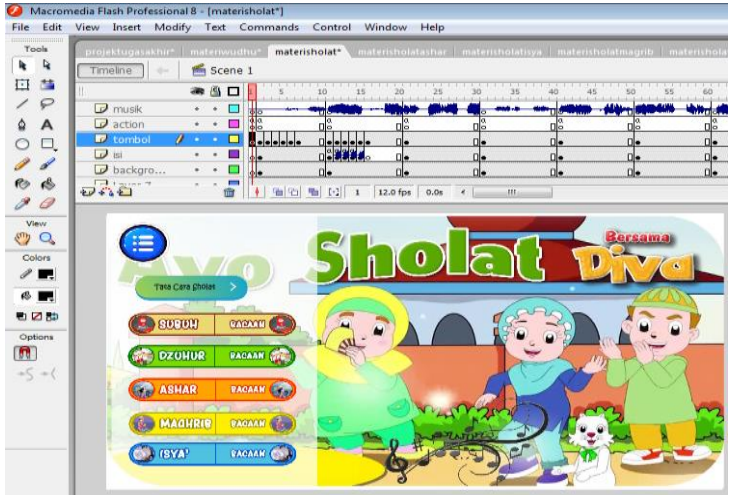

Gambar 18. Tampilan Halaman Utama Sholat

\section{Tampilan Halaman Sholat}

Tampilan ini berfungsi untuk menampilkan tata cara sholat dengan diiringi musik terdapat tombol menu untuk kembali ke halaman materi sholat dari user yang ActionScriptnya :
on
(release)
\{gotoAndStop(1); stopAllSounds(); \}

19

Berikut tampilan halaman sholat seperti gambar

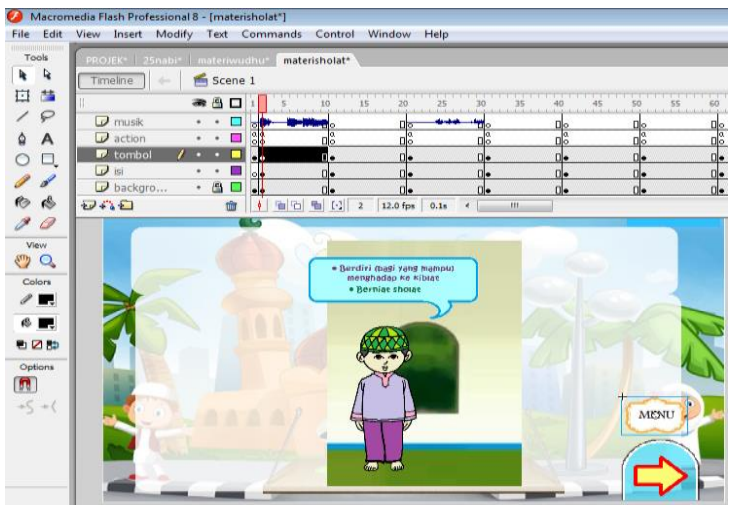

Gambar 19. Tampilan Rancangan Halaman Sholat

\section{Tampilan Halaman Intro}

Halaman intro merupakan halaman yang berisi judul dari aplikasi multimedia ini. Untuk masuk Kedalam halaman materi klik tombol materi. Tampilan halaman intro dapat dilihat pada Gambar 20

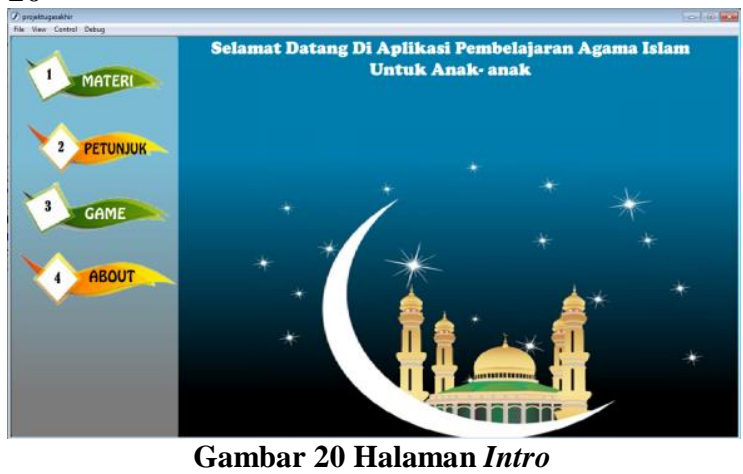




\section{Tampilan Halaman Menu Materi}

Halaman menu materi memiliki 3 button yaitu button kisah 25 nabi dan rasul, tata cara wudhu, tata cara shalat, Tampilan halaman menu materi dapat dilihat pada Gambar 21

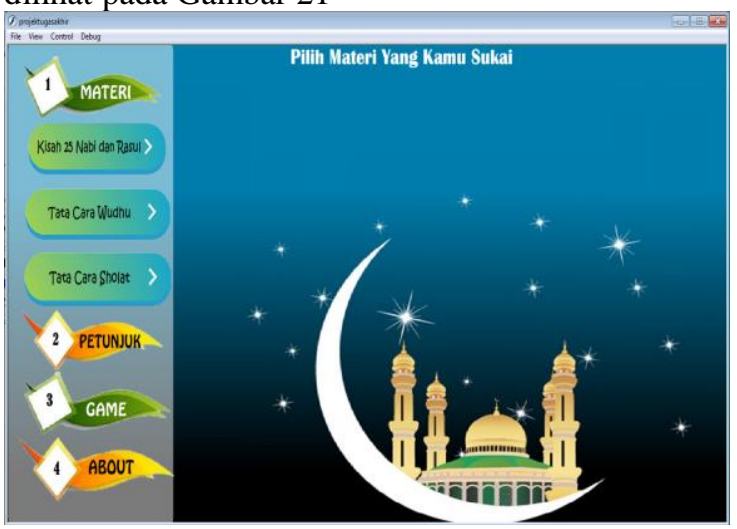

Gambar 21. Halaman Menu Materi

\section{Tampilan Halaman Menu 25 Nabi dan Rasul}

Halaman menu 25 nabi dan rasul memiliki 25 submenu. Disetiap menu nabi memiliki kisah-kisah para nabi dan rasul. Tampilan halaman menu 25 nabi dan rasuldapat dilihat pada Gambar 22

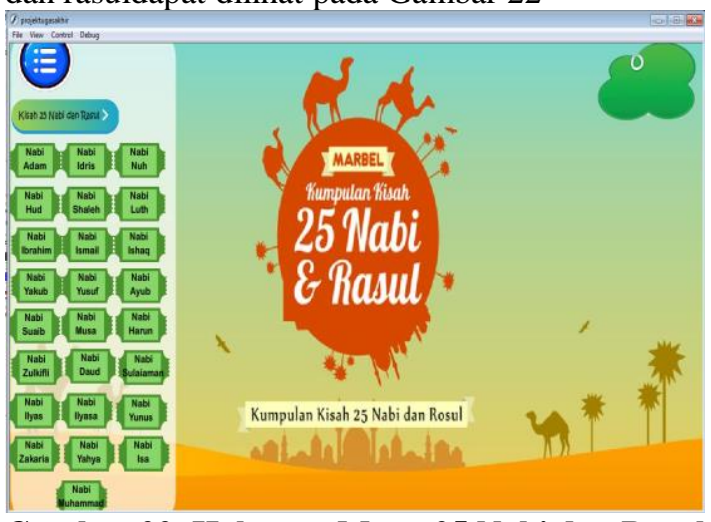

Gambar 22. Halaman Menu 25 Nabi dan Rasul

Tampilan Halaman Kisah 25 Nabi dan Rasul

Halaman lembar kisah 25 nabi dan rasul merupakan halaman yang nemampilkan kisah nabi-nabi dan rasul dengan diiringi audio disetiap menu nabi. Terdapat tombol untuk kembali ke menu 25 nabi dan rasul. Halaman lembar kisah 25 nabi dan rasul dapat dilihat pada Gambar 23.

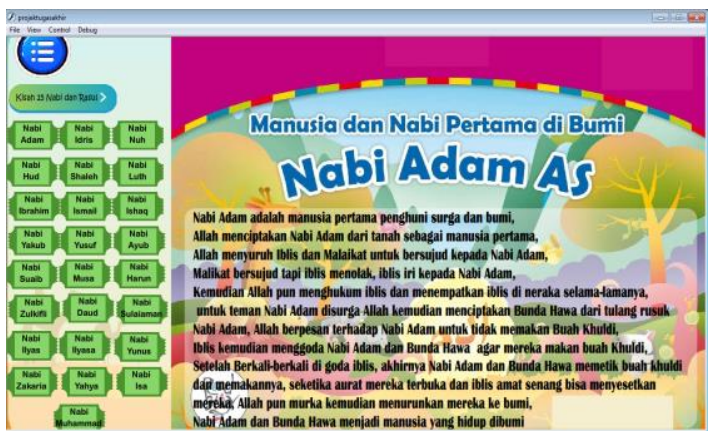

Gambar 23 Halaman Kisah 25 Nabi dan Rasul

\section{Kesimpulan}

\section{Kesimpulan}

Membuat aplikasi multimedia Interaktif Sebagai Media Pembelajaran Agama Islam Untuk Anak-anak sebagai alternatif sistem pembelajaran yang efektif, menarik dan mudah dipahami oleh anak-anak dengan konsep belajar sambil bermain diharapkan dapat meningkatkan minat anak-anak untuk belajar dan memudahkan orang tua dalam mengenalkan agama islam kepada anak-anak.

Saran

Perlunya pengembangan desain tampilan, penambahan materi dan soal-soal dalam game agar aplikasi ini dapat menjadi media pembelajaran efektif bagi anak-anak dalam mempelajari agama islam.

\section{Daftar Pustaka}

[1] Hanafri M.I, Ramdhan S dan Nisa K. (2017). Pembelajaran Interaktif Pengenalan Profesi Berbasis Multimedia Menggunakan Adobe Flash CS6. Jurnal Sisfotek Global, (7) 2.

[2] Winaryono D \& Setiawan E.B. (2015). Pembangunan Aplikasi Pembelajaran Multimedia Interaktif Mata Pelajaran Fikih Kelas IV di MI MIFTAHUSSALAM BANDUNG Berbasis Desktop. Jurnal Ilmiah Komputer dan Informatika (KOMPUTA), (1) 1.

[3] Hidayat T \& Palupi A.E. (2013). Penerapan Media Pembelajaran Berbasis Macromedia Flash 8 Melalui Pembelajaran Langsung Untuk Meningkatkan Hasil Belajar Pada Pelajaran Mesin CNC TU 2A Siswa Kelas Xi TPM 3 Di SMK Negeri 3 Boyolangu. JPTM (2)1.

[4] Kurniawan T.D.(2016) Pengaruh Penggunaan Media Video Pembelajaran Terhadap Prestasi Belajar Ilmu Pengetahuan Sosial Siswa Kelas V SD Se-Kecamatan Gedangsari Gunung Kidul Tahun Ajaran 2015/2016. Trihayu: Jurnal Pendidikan KeSD-an, (3)1, 21-26.

[5] Muhtadi \& Maghfiroh R.A (2018) Nilai-Nilai Pendidikan Agama Islam dalam Sholat Berjamaah. Sumbula(3) 1, 783-807

[6] Adelia \& Setiawan J.(2011). Implementasi Customer Relationship Management (CRM) pada Sistem Reservasi Hotel berbasis Website dan Desktop. Jurnal Sistem Informasi, (6)2, 113 - 126.

[7] Nozomi, I. (2018). APLIKASI GAME EDUKASI PADA ANAK USIA 5 SAMPAI 10 TAHUN DENGAN METODE IMAGE MANIPULATION. INTECOMS: Journal of 
Jurnal Sains, Teknologi dan Industri, Vol. 17, No. 2, Juni 2020, pp. 50 - 58 ISSN 2407-0939 print/ISSN 2721-2041 online

Information Technology and Computer

Science, 1(2), 124-131. 